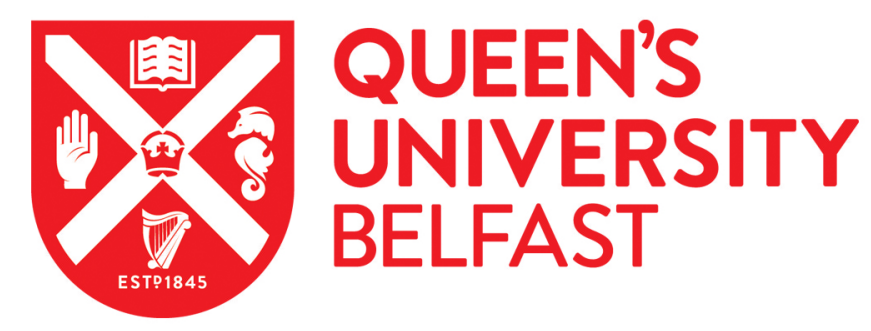

\title{
Precarity, Rights and Resistance in the Everyday Lives of Children and Young People
}

Leonard, M. (Accepted/In press). Precarity, Rights and Resistance in the Everyday Lives of Children and Young People. Journal of Sociology, 56(3), 405. https://doi.org/10.1177/1440783319846187

Published in:

Journal of Sociology

Document Version:

Peer reviewed version

Queen's University Belfast - Research Portal:

Link to publication record in Queen's University Belfast Research Portal

Publisher rights

(c) 2019 The Authors. This work is made available online in accordance with the publisher's policies. Please refer to any applicable terms of use of the publisher.

\section{General rights}

Copyright for the publications made accessible via the Queen's University Belfast Research Portal is retained by the author(s) and / or other copyright owners and it is a condition of accessing these publications that users recognise and abide by the legal requirements associated with these rights.

Take down policy

The Research Portal is Queen's institutional repository that provides access to Queen's research output. Every effort has been made to ensure that content in the Research Portal does not infringe any person's rights, or applicable UK laws. If you discover content in the Research Portal that you believe breaches copyright or violates any law, please contact openaccess@qub.ac.uk. 


\title{
Precarity, Rights and Resistance in the Everyday Lives of Children and Young People
}

\begin{abstract}
:
The overall theme of the 2018 TASA Conference on 'Precarity, Rights and Resistance' has particular relevance for understanding the everyday worlds of contemporary childhood. This article addresses the relevance of these three concepts in general terms in relation to children and young people in 'developed' societies and then specifically explores how this triple lens enables children's perspectives and experiences of growing up in 'post-conflict' Belfast to be understood. The concept of 'generagency' is introduced as providing a useful conceptual tool for exploring the multiple and contradictory landscapes of childhood and how precarity, rights and resistance are experienced generationally.
\end{abstract}

\section{Generation and Childhood}

A common starting point for exploring generation is Mannheim's seminal work published in 1952. It is worth pointing out that Mannheim did not specifically focus on children but he did suggest that an awareness of generation often begins in adolescence. His core thesis is that generational cohorts based on age may share and experience a common history and by living through the same historical and political period, cohorts come to acquire similar attitudes which in turn have the potential to turn into a shared consciousness that ultimately can facilitate social transformation. This work has had a significant impact on youth studies in Australia. Wyn and Woodman (2006) have developed the notion of 'social generation' as a way of understanding the everyday lives of contemporary youth in Australia and elsewhere by paying attention to the specific material conditions which shape their everyday lives. This concept is utilised not as another way of applying a staged, transitional approach to adulthood but as a lens through which to understand the multiple ways in which young people actively construct and influence their everyday lives within wider given circumstances (Furlong et al. 2011). In other words, following Mannheim, this work emphasises and illustrates how the meaning of age is influenced by social conditions. The significant and prolific work associated with the Life Patterns study has revealed how changes in education and employment have impacted on contemporary Australian youth and how in turn they subjectively respond to these changing circumstances (Wyn et al. 2012; Woodman, 2012). The generational framework employed 
enables an understanding of the subjectivities of contemporary Australian youth but located within the constraints of wider economic, social, cultural and political circumstances.

My usage of generation is closely related to the work of Wyn and Woodman (2006), however, I locate myself theoretically within childhood studies rather than youth studies although, in the process I do not want to create a 'false binary' between the two. As Furlong et al. (2011: 361) point out 'the boundaries of childhood, youth and adulthood are blurred, indistinct, porous and changing. Wyn (2015) outlines how childhood studies and youth studies have become increasingly interdisciplinary or multidisciplinary subjects drawing on geography, development psychology, politics, economics, history and other disciplines but despite this burgeoning of multi-disciplinary frameworks, there is still need to develop more effective links between childhood studies and youth studies. Childhood studies and youth studies continue to rest on different sets of assumptions, concepts and frameworks about the nature, meaning and experience of children and youth. A generational framework may provide a useful framework for drawing on the insights childhood theorists and youth theorists have contributed to understanding the everyday lives of children and youth at both the macro and micro level. Hence, in the remainder of this paper, I want to outline how childhood theorists have contributed to debates on generation and how this approach has influenced my work on teenagers in Belfast.

My theoretical approach draws on the work of a number of core childhood sociologists (Mayall, 2002; Alanen, 1994; Qvortrup, 1994). These theorists look at how generation plays out in the here and now, how children are impacted by their generational location in the present and their capacity for social transformation in the present rather than their ability to develop a shared consciousness in childhood that might lead to social transformations in their later adult lives as implied in Mannheim's approach. Understanding childhood necessitates illuminating how it is different to adulthood. The category childhood only makes sense in terms of its relationship to and separation from adulthood. This is not to simplistically reduce childhood to an age related status nor is it to suggest that children or indeed adults are homogeneous groups. Rather it is to acknowledge that a wide range of social, cultural, economic, political and discursive processes differentiate childhood from adulthood. Hence, understanding childhood involves subjecting adulthood to theoretical scrutiny. In other words, at least in minority world societies, generation is a structural process similar to other macro-structural processes such as class, gender and ethnicity. In adopting this position, it is not my intention to suggest that childhood and adulthood are dualistic nor oppositional positions. Rather, my 
intention is to explore generation as a relational process with connections between the two being messy, ambiguous and interrelated rather than stable, durable and separate. Generation is therefore a vehicle for exploring the nature of child-adult relationships within wider structural cultural, economic, social, legal and political environments.

A number of childhood theorists (Qvortrup, 1994; Alanen, 1994, Mayall, 2002) have utilised the notion of a 'generational order' as an analytical framework to illuminate how children and adults are located within existing generational categories that produce and reproduce reciprocal generational relationships. Hence, understanding these generational practices is essential to comprehending how childhood and adulthood are internalised, performed, challenged and modified in multiple ways as children negotiate childhood and adults negotiate adulthood and in the process dilute and refine the porous boundaries between the two positions. Children and adults occupy specific positions based on generation related to specific social structures which impact on how each relate to the other. Moreover, as a minority group children are impacted by resilient power relations based on generation. While generation is a facet of this ordering, it is also not separate from other structural, albeit socially constructed, orderings such as gender, class and ethnicity but adding generation to the mix enables more relevant interrelationships to come to the fore that aid our understanding of how childhood and adulthood are inter-generationally accomplished and practiced and how they play out in relation to their gendered, classed and ethnic dimensions.

Bringing generation into the equation should not be seen as simplistically adopting a dualistic approach to childhood and adulthood. Prout (2005) for example, argues that modern childhood reflects weakening boundaries between each location rendering such dichotomous positions as unsustainable. However, our discourses, our theoretical reflections, our research practices, our political and economic systems continue to shaped by these categorical constructs and in working within these distinctions my intention is not to simplistic reify such boundaries but to elaborate and illuminate the relational aspects of childhood and adulthood. Hence while my work is located within the constructs of childhood and adulthood, my intention is to see relationships between the two as dynamic rather than fixed. But to do this, one needs to acknowledge how these dualisms are already present within childhood studies and indeed how childhood studies has become a trendy sub-discipline with its own child friendly methods within sociology rather than the discipline responding to Lee's (1998) call for 'an immature sociology'. In Lee's view, 'the sociology of childhood maintains 'the privilege of the complete and the mature over the incomplete and the immature' and this has fundamental consequences 
for the new sociology of childhood's mantra that children are active agents and this will be returned to later in the article. Hence while I am aware that working within these categories is in danger of reifying their existence and Connell's work on gender reminds us of the limitations of applying such categorical devices, my intention is to use these dichotomies to exemplify their interpenetration rather than separation and in the process to render these dualisms as artificial and questionable.

In the remainder of this article, I will use generation as conceptual tool for understanding how precarity, rights and resistance impact on the structural nature of childhood and drawing on research with children in 'post conflict' Belfast illustrate how children actively engage with and dilute these generational structures. Before turning to these issues, some qualifications are necessary. I am using the UNCRC definition of the child as persons below the age of 18 and while my research draws mainly on the everyday worlds of young teenagers I will refer to this age group using the terms children, teenagers and young people interchangeably but locating myself theoretically within childhood studies. Moreover, the spatial focus of my discussion draws on children and childhoods as experienced in minority world countries. Bringing in global childhoods particularly lived childhoods in majority world societies brings in further complexities regarding terminology and renders problematic distinctions that I am going to make between childhood and adulthood, reminding us that children are subject to very different historical, economic and cultural contexts which impact on how childhood is perceived, defined, inhabited and experienced in different spatial milieu.

\section{Precarity and Childhood}

In adopting a generational approach to account for the structural location of childhood in modern 'western' societies, Qvortrup (1994) turns to the emergence of the industrial revolution and its impact on childhood and adulthood and relations between the two. While sending children out to work in other households was common practice prior to the industrial revolution, the initial impact of the industrial revolution was to make it more economically viable for children to remain in the household and contribute to the household economy through paid work. However, throughout the second half of the $19^{\text {th }}$ century, a range of legislative reforms were introduced to remove and separate children from the world of work. Cunningham (2012) outlines how this period ushered in new conceptions of childhood based on children's economic dependency on adults and on idealised and romanticised notions of how childhood 
should be lived and experienced. The introduction and spread of compulsory schooling enhanced this trend resulting in further separation of children from adults. Childhood was to be characterised by education while adulthood was to be characterised by work. Zelizer (1994: $\mathrm{x})$ outlines how the child became 'economically useless' but 'emotionally priceless'. Hendrick's (1990) work on the history of childhood throughout the $20^{\text {th }}$ century shows how a range of wider institutions developed a new notion of childhood based on separating the child from the adult and as a consequence of these changes childhood emerged as a 'distinct form of age inequality which rests on the socially dependent status of the young' (Bradley, 1996: 176).

This very brief review argues that the onset of the industrial revolution resulted in a profound transformation in the social value of children. The period serves as a useful lens for exploring and illuminating how childhood became separated from adulthood with generational location emerging as a significant structural component of modern 'western' societies. Roles and expectations became closely linked to and divided by generation. Notions of different child-adult traits found expression in a range of emerging social policies which often endorsed and legitimised generational differences. The family serves as one example of this. Up until the middle of the $20^{\text {th }}$ century, families were structured around idealised gender roles reflected in the work of Parsons (1954) who saw men and women taking on complementary, relational roles with men working outside the household as main breadwinners while women were relegated to the status of homemakers and mothers with one of the primary functions of the family being to socialise children into these pre-determined adult roles. As Parsons puts it 'when children are born, they are like pebbles thrown into a social pond. First the family and then schools and other institutions shape the growing child who comes to internalise the values and rules of adult society'. Of course, this idealised family form never fully existed and from the 1970s onwards, major societal changes impacted on family forms with children's experiences of family life becoming ever more complex. Rising divorce rates and the decline in the stigma attached to lone parenthood resulted in more and more children likely to grow up in households without fathers. The biological link between parents and children became more diverse due to marriage, remarriage, cohabitation, fostering, adoption and artificial insemination meaning that children are likely to encounter a range of different adults during their childhood years. Hence family life has become more precarious, more unstable and more uncertain.

Economic precarity also characterises many children's everyday lives. A bourgeoning range of social welfare policies based on the mantra that poor children become poor adults has 
resulted in the emergence of social investment welfare (Lewis, 2006). This future orientated approach locates children as 'human becomings' with policies centring on preventing the transmission of inter-generational poverty. However, many accounts of child poverty fail to give children 'conceptual autonomy' (Thorne) drawing on the household as a unit of analysis and assuming that what is good for adults in the household is also good for children. Research in Ireland into the everyday lives of members of poor households revealed that children's conceptions and experiences of poverty were very different to those of adults and called into question poverty indicators devoid of child input (Daly and Leonard). As a result, policy drivers have often prioritised enabling adults to enter the labour market rather than promoting the needs of children. Recent research into the experiences of lone mothers in Northern Ireland to activation welfare policies reveals how many struggle with the new demands of motherhood which commodifies childcare outside the household and renders as economically inactive, women who undertake a parenting role (Leonard and Kelly, 2017). They also bring children into the realm of private childcare forging ever increasing intergenerational relationships between adults and children. As adults' working lives have become more economically fragile due to the increasing prevalence of zero-hour flexible work practices, this has impacted on how childhood is increasingly experienced as a precarious location. Youth sociologists in Australia have outlined these consequences for youth in terms of how adulthood in relation to economic independence from parents have been postponed as youth struggle to establish independent homes and relationships with increasing economic precarity limiting opportunities for independence from existing adult relationships. This underpins how 'the long reach of childhood' (Merz, 2013) impacts on youth and adulthood.

\section{Rights}

It is now commonplace to see children as rights holders. This was enshrined in the UNCRC (1989) which positioned children as human beings with entitlements to rights rather than passive objects of care and charity (www.unicef.org/crc). The 54 articles of the Convention are typically grouped under what are referred to as the three Ps: Protection, Provision and Participation. While previous Declarations highlighted states' duties in relation to protecting children and providing for their needs, it was the inclusion of articles related to participation that enabled the UNCRC to be considered as a watershed in the field of children's rights. The two articles commonly considered as the most influential have been Article 3 which emphasises that the child's best interests should be reflected in all state policies and Article 12 which encourages states to set up frameworks for ensuing that children participate in decisions which 
impact on them through expressing their views with these views being 'given due weight'. Freeman (1996) argues that the Convention is a 'soft law' setting up moral obligations in relation to having respect for the child's views with states making period reports to the UNCRC and being subjected to critical audit to determine the extent to which their policies reflect the best interests of children and take their views into account. However, a generational approach remains apparent in terms of how the UNCRC enshrines distinctions between children and adults by specifying child rights rather than human (adult) rights. Hence, at a global level, while the Universal Declaration of Human Rights applies to individuals of all ages, it specifies how children are entitled to additional special care and assistance. This acknowledgement that children are vulnerable in ways that adults are not and hence need additional protections provided much of the rationale for setting up a Convention that would locate children and childhood as a specific age category separate from adulthood. While Article 3 and 12 enabled a more active role for children in decision making processes and facilitated a movement towards developing frameworks for obtaining, listening and responding to their voices, the Convention in practice, sets up distinctions between adults and children. Article 3.2 for example states

State Parties undertaken to ensure the child such protection and care as is necessary for his or her well-being, taking into account the rights and duties of his or her parents, legal guardians or other individuals legally responsible for him or her....

In a similar vein, while Article 12.1 accords the child the right to express their views 'freely in all matters affecting the child', it goes on to specify that the child's view should be 'given due weight in accordance with the age and maturity of the child'. Who defines maturity here? Other articles in the Convention offer a clear role for adults in determining the extent to which children can 'freely' hold rights. Archard and Skivenes (2009) argue that overall the Convention pulls in two contradictory directions, on the one hand, advocating states to act in the child's best interests but, on the other hand, locating a range of adults as fundamental interpreters of children's competency to exercise rights and to define their best interests. This is illustrated with reference to Article 5 which states:

State parties shall respect the responsibilities, rights and duties of parents or, where applicable, the members of the extended family or community as provided for by local custom, legal guardians or other persons legally responsible for the child, to provide in a manner consistent with the evolving capacities of the child, appropriate 
direction and guidance in the exercise by the child of the rights recognised in the present Convention.

The upshot of this is that locating children within generational structures is implicit throughout the Convention. A number of researchers have outlined messy examples of what happens when children's rights and adult rights collide and in resolving these tensions, all sorts of assumptions concerning the nature of childhood compared to adulthood are brought into play. Adults are often located as the primary judges of the child's best interests. Archard and Skivenes (2009) give an example of a girl who needed a life-saving heart transplant. The girl considered her options and decided against the transplant as she did not want to undergo the surgery, have someone else's heart in her body and take tablets for the rest of her life. She was aware that refusing the transplant could have fatal consequences but felt that this was a preferable option. During the ensuing Court case to decide on her level of competency, the Court ruled that the girl was not fully aware of the consequences of this decision and was not competent enough to be the judge of her own 'best interests'. Research suggests that when children refuse any life-extending treatment, they are deemed as acting incompetently (Alderson and Goodwin, 1993). The point to emphasise here is that when adults take such decisions their choices are respected even if there is widespread disagreement among members of their family networks. Besson (2005) argues that the UNCRC has ghettoised children's rights setting up boundaries between children's rights and human (adult) rights and in the process creating unresolved tensions between the positions of childhood and adulthood in relation to holding and exercising rights.

I now want to turn and look in more detail at Article 12 which gives children a voice and advocates states to adopt frameworks to ensure that their voices are listened. This has encouraged a proliferation of research which prioritises children's rights to participation as a fundamental child right. Hence, within academia, children's rights have been defined mainly by their right to participate in research and this has led to a whole host of research practices under the umbrella term of participatory research. Participatory research methods have been embraced by the majority of childhood researchers as a less hierarchal approach which locates children as research collaborators rather than research objects (Pain, 2004). The approach positions children as holding valid knowledge about their everyday lives and experiences which participatory methods can unleash through children's active involvement in all stages of the research process. Those who advocate such methods argue that the broad approach is more than a mere set of techniques, fundamentally, it is a political commitment to enable the voice 
of the researched to be heard, listened to and acted upon (Cahill, 2009). As Schaefer and Yarwood (2009: 125) put it, participation is not reducible to a 'specific set of methods but as the outcome of engagement and negotiation as well as knowledge-sharing and shared decision making'.

The mantra 'children are experts of their own lives' is a common claim within participatory approaches to researching childhood. Indeed, one of the perceived core strengths of participatory research is the extent to which it offers epistemological advances over traditional methods. By locating children as expert holders of knowledge about childhood, the methodology is seen as producing authentic accounts of childhood by privileging children's voices (Grover, 2004). Closely connected to claims about the epistemological benefits of participatory methods in their capacity to produce more accurate and relevant accounts of childhood from a 'genuine' child perspective is the ability of participatory methods to confront the power relationships that underpin adult-child relationships. By setting up a collaborative research framework, adult researchers transfer some of their power to children. By challenging the expertise of the adult researcher through enabling children's specific insights and experiences to come to the fore, power becomes less imbalanced and less weighted in the adult's favour.

This redistribution of power within micro research relationships at times fails to take sufficient account of wider power relationships including the hierarchal settings in which most childhood research takes place such as schools, youth clubs and other child dominated settings and the various adult gatekeepers whose permission has to be obtained in order to give the child 'voice' (Leonard, 2007). Of course, power between adults and children is not fixed but likely to operate at multiple levels and be continually negotiated. As Foucault (1980) reminds us power is never unidirectional and also includes possibilities for resistance but it remains important to acknowledge this wider power infused framework.

Punch (2002) argues that there is a fundamental conundrum underpinning the embracement of participatory research in that if children are now positioned as competent by childhood researchers then why do we need 'child friendly' methods to understand and articulate their accounts of their everyday lives. She argues for 'person friendly' rather than 'child friendly' methods. Gallagher (2009) also cautions childhood researchers not to overclaim the benefits of participatory research over other methods. Drawing on Cook and Kothari (2001), he calls into question the 'tyranny of participation' whereby almost every aspect of 
children's everyday lives is now subjected to the adult gaze under the dubious premise that involvement in research itself, through the methodological approach taken, is a form of empowerment. As Gore (1992:63) points out, the researcher may not know 'what would be empowering for others'.

Moreover, while great claims are made about the capacity of participatory research methods to empower young people and enable them to exercise agency, these processes can also have exclusionary and disempowering effects. The rise of the child expert accessed through school councils, advisory groups etc. result on some children's voice being heard more than others (Wyness, 2009). Moreover, Gallacher and Gallagher (2008) point out an ontological quandary in relation to the extent to which the self is knowable and that this reflexive insight can be captured by using the right methods. In practice the ever reaching adult gaze may have unintended consequences by reinforcing rather than challenging the hierarchal relationships between children and adults with children unwittingly become involved in the production of knowledge which is subsequently utilised to further regulate their everyday lives and experiences. Moreover, participatory research is often affected by funding requirements and imbued with personal and professional interests. Kitchen and Hubbard (1999) suggest that rather than benefiting research participants, participatory methods may in reality benefit academics seeking career progression and funding opportunities.

\section{Resistance and agency}

Prout and James (1990) in outlining their new paradigm for the sociology of childhood located children as active agents with the capacity to shape their own lives, the lives of those around them and the wider society. Resistance underpins this approach. Rather than the objects of socialisation or the passive recipients of the dominant discourses that underpin development psychology which implies an almost deterministic developmental staged journey towards adulthood, young people are relocated as active actors with a capacity to accept, challenge, resist and transform the processes that impact on their everyday lives and underpin their social relationships with adults and each other. Hence, agency and resistance go hand and hand and the merging of the concepts have become a critical feature of contemporary theorising within childhood studies. A number of childhood theorists argue that agency needs to move away from categorisations of individual rational actors demonstrating free-will towards accounts which show the importance of generation along with its classed, gendered and raced 
dimensions. Structure is produced, reproduced and transformed within and across child-adult relationships and agency is exercised and practiced within the everyday spaces of adulthood and childhood. Generation provides a framework for understanding more fully how childhood and adulthood is produced and practiced within frameworks that enable and constrain the everyday attitudes and practices of both children and adults.

In order to capture this interplay, I introduce the concept of generagency (Leonard, 2016). The concept brings together the mutually reinforcing, interdependent but continually dynamic relationship between agency and generation. In offering this concept, I do not want to imply that a neat division exists between childhood and adulthood. I acknowledge that there are strong commonalities between the two and that adults along with children are in a constant process of 'becoming' as they struggle with, challenge and reshape what it means to be a child or an adult but my intention is to shed light on how wider society encourages profound differences between the two and utilises the labels of childhood and adulthood as markers of differences exemplified in a range of social, cultural, political and economic frameworks. I appreciate that this conceptualisation can be criticised for implying singular, polarised, fixed and separate identities of the child and adult. Again, this is not my intention. Rather my aim is to merge the structural location of childhood and the generational positions it produces with children's (and adults') ongoing capacities for practicing and realising agency within and across these generational categories. By locating children within generational power structures, I aim to provide a more nuanced approach to agency. Generational relationships are enacted within everyday lives and agency, rather than a possession, is held and practiced within and across generational relationships. Agency cannot be divorced from any reflection on structure. Hence, while childhood and adulthood produce multiple, fluid, shifting and dynamic interactions, the structural influence of society's wider imposition of generational ordering through its social, cultural, economic and political systems needs to be kept in play.

My conceptualisation of generagency is broken down into two components: intergeneragency and intra-generagency. Intergeneragency sheds light on the multiple points of resistance and spaces whereby children are able to exercise power over adults. Children and young people should not just be considered as active agents but as 'agents of change' (Ginwright and James, 2002). Intrageneragency sheds light on the power relationships that exist within childhood and young people themselves. It is not just children but also adults who experience power imbalances within their everyday lives. Intrageneragency enables us to illuminate the complexity and heterogeneity that exists within the umbrella term of childhood 
and allows reflection on the multiple power relationships that occur within their everyday relationships with each other. Rather than a homogenous group, children are constantly managing, negotiating, challenging and transforming the power relationships that emerge from their interactions with each other. I now turn to how the concepts of precarity, rights and resistance enables understanding of young people's everyday lives in 'post conflict' Belfast and how my concept of 'generagency' provides a broad framework for exploring in the impact of generation in their everyday lives.

\section{Growing up in Post Conflict Belfast: issues of precarity, rights and resistance}

The research I am drawing on here was part of an ESRC funded project Conflict in Cities and the Contested State (www.conflictincities.org). The overall aim of the project was to locate divided cities as key sites of ethno-national conflict and to explore how the architecture of divided cities and the everyday spatial practices of residents created possibilities for transformation. As part of this project, my research explored the extent to which teenagers growing up in segregated Catholic and Protestant residential areas perceived and experienced the city as shared or divided space. The research adopted a participatory research methods framework, drawing an Advisory Group of young people to help with the design of the research and to give advice on how the research should be carried out. A wide range of methods were utilised including questionnaires, focus group interviews, photo-elicitation with the Advisory Groups guiding the process. In relation to the questionnaire, the Advisory Group suggested adding and removing questions from the questionnaire and the made productive comments on the overall layout which was altered in line with the comments made. They also impacted on the photos used during the photo-elicitation exercise including advising me on the selection of photographs, the order in which they were shown to research participants and how the subsequent focus groups to discuss the photographs should be organised.

As the research progressed, the Advisory Group became actively involved in the research design, meeting us at weekends to walk around the city centre of Belfast in recognition that our wider research was taking place in schools where teenagers were immobile yet being encouraged to talk about their out-of-school spatial practices. They also took photographs of what Belfast meant to them and what spatial locations they would prioritise. The location of Belfast as a core tourist destination came up repeatedly in discussion groups with the wider research population, particularly how their areas with their trappings of sectarian affiliation via the visual display of Irish and British flags, political wall murals commemorating loyalist and 
Republican sentiments and the ongoing presence of 'peace walls' had morphed into 'dark tourism' sites. Many teenagers questioned dominant narratives around Belfast as a city that has left its past behind and the unproblematic location of Belfast as a 'post conflict' society and in light of this, the Advisory Group suggested that they organise their own tour of Belfast and take control of what they would prioritise and show to tourists to demonstrate Belfast's dual status as a divided and shared city (Leonard, forthcoming). This was not part of my original research design but I responded positively to this suggestion locating the teenagers' participation in terms of facilitating their involvement as co-researchers. In this context, the research operated within a rights based framework around the right of children to actively participate in knowledge production, the right to be involved in all stages of the research process and the right to have their voices implemented at various stages of the research process. However, bearing in mind my earlier discussion, I do not want to imply that power relationships were not present through the research process. Elsewhere I have discussed and problematized the extent to which children and young people have the ability to exercise power in research relationships (Leonard, 2017). Following Franks (2011), the research framework attempted to give children 'pockets of power' while recognising how wider generational relationships impact on adult-child social relations.

The young people located themselves as rights holders in terms of their right to the city and its local and central spaces. These rights were discussed in terms of their peer networks and how this impacted on their use of local and city centre space. Ethno-national identification was important in terms of Protestant and Catholic affiliation and its impact on unionist and national identity constructions. Although the communities where the research was conducted were adjacent to one another, for the most part teenagers stayed within their own communities and exhibited an unwillingness to enter the space of the other community. They built up information networks around safe and unsafe spaces and utilised the sectarian markers of differences that permeated each community as indicators of inclusion and exclusion. They justified exclusionary markers in terms of the right of each community to exhibit commitment to a loyalist or republican identity. However, rights were expressed as competing rights or at best complementary rights rather than being related to wider discourses around equality and citizenship.

The economic precarity of their communities featured prominently in the research along with their own position as dependents within their households. The impact of 'the troubles' on the population of Northern Ireland has always been spatial with interface areas particularly 
affected. Shirlow and Murtagh (2006) for example calculate that between 1969 and 2004, one third of the victims of politically motivated violence were murdered within 250 metres of an interface area while the figure rises to $70 \%$ of all murders when the spatial gaze is extended to 500 metres. Of the 257 children who lost their lives as a result of the conflict, just under half came from North and West Belfast and the specific areas where this research was carried out were particularly affected. These areas repeatedly appear in statistics on economic deprivation with OFMDFM statistics showing that 14 of the 15 most deprived communities in Belfast are interface communities (OFMDFM, 2010). Gaffikin et al (2016) suggest that these areas are embroiled in a 'race to the bottom' striving to be labelled as the most deprived community in order to gain access to funding.

This economic precarity has significant impact on the teenagers who took part in this research. Very few teenagers had any part-time employment reflecting the earlier discussion on young people's exclusion from the labour market and this enhanced their financial dependency on economically disadvantaged parents. While of course most 'western developed' states have legislation permitting young people usually between the ages of 13-16 to have part-time employment, research on working children in Australia, the UK and elsewhere repeatedly show that opportunities are more prevalent for middle-class children through their access to more economically privileged adult networks (references). This in turns means that they are more impacted by insular local spaces. Residential and educational segregation remains a core feature of growing up in Northern Ireland. Shuttleworth and Lloyd (2008) point out that $94 \%$ of social housing estates in Belfast are single identity communities. A similar picture emerges when one looks at the educational system with around $94 \%$ of school pupils attending schools segregated according to Catholic/Protestant backgrounds (Hamilton et al. 2008). Other research suggests that for segregated communities in particular, the employment market takes people outside their communities and thus enhances their opportunities of mixing in the workforce and forming cross-community friendships and networks (Shuttleworth and Anderson, 2002). Young people are more constrained in their ability to do this given their exclusion from the labour market leading to the entrenched parochialism which characterises their everyday lives and constrains their spatial movements.

Of course, this does not mean that teenagers never leave their communities, they do. The city centre emerged as a core location for meeting up at the weekends and for shopping and other leisure pursuits. Moreover, teenagers for the most part saw city centre space as shared space. However, focusing on their spatial practices in terms of accessing and using city centre 
space suggests the need to critically unpack what shared space means in practice. Young people stood at different bus stops and at times took different routes from geographically close locations into the city centre. They visited the city centre in pre-formed residential groups or friendship groups emanating from their segregated school backgrounds. As a result, their spatial practices revealed the parallel use of shared city centre locations calling into question the need to critically unpack what shared space means for Belfast and indeed other cities that may operate along other lines of inclusion and exclusion.

Where do child-adult relationships fit in here? The research participants themselves brought in the generational order as having a significant impact on their daily spatial practices both locally and in the city centre. While my focus on Belfast as a divided or shared city was examined through a teenage ethno-national lens and at times, brought in additional variables such as class and gender, research participants suggested that this lens needed widened to examine child-adult relationships and how these impacted on their spatial practices. Young people discussed, at various stages, throughout the research process, how adults often positioned them as 'out of place' (Sibley, 1995) both in their localities and in city centre spaces. As has been highlighted in other childhood research, young people talked of hanging around street corners at night time and of being moved from one street corner to another by various groups of adults in their communities despite their insistence they had nowhere else to go. In relation to city centre spaces, almost three quarters of the overall sample indicated that they were viewed with suspicion by other adults and shop workers. Moreover, being regarded as negatively by security guards was referred to in questionnaire responses, came up repeated during focus group interviews and was highlighted during 'walk and talk' interviews with members of the Advisory Group. Hence young people argued that my research lens needed to be widened to consider how Belfast was experienced as divided or shared along intergenerational lines with many adults seeing the city centre as adult space which may be shared with children as long as relevant adults such as parents were present but which was problematized when groups of young people accessed city centre spaces independently.

There were many other instances where child-adult relationships permeated the research and influenced their capacity to exhibit agency in Giddens' terms in terms of impacting on wider social structures although resistance was ever present. For example, the overall research design in terms of accessing respondents and obtaining permission for the various methods to be employed was dependent on the consent of various adults. Hence, regardless of how 'child friendly' or 'participatory' the intention, young people as research 
participants were located at the bottom of the chain of gatekeepers that I had to access in order for the research to be carried out. Parents had to sign consent forms, Youth leaders had to agree access to the Advisory Group. This is not to suggest that adults as gatekeepers are a homogeneous group. The gatekeepers were in hierarchal relationships within adulthood. For example, the broader research took place within schools and principals were the first point of contact. There were times when it is obvious that the principal equated her/his consent with than of the class teachers so I was imposed on the teacher and had to try and distance myself from the implication that I was complicit in this consent process.

This highlights the fallacy of seeing power as a commodity possessed by one group (adults) and inflicted on another group (children). Power is complex and multi-variable but it often emerges from and is practiced within and between generational relationships. Within these wider networks, adults made decisions on whether or not children could take part in the research. Childhood researchers commonly discuss these issues stressing the importance of not equating adult consent with child consent and giving all sorts of useful advice in how to secure the child's active consent.

For the most part, schools were the location for the research as I wanted to access 'ordinary' teenagers from both communities and since schools require compulsory attendance then all local teenagers attend schools. These teenagers differed from those who formed the Advisory Group as teenagers had volunteered to join these groups and therefore their status as typical teenagers were more questionable. There were various differences in the spatial practices of teenagers from interface areas and those of the Advisory Group, all living in the same city illustrating how being a teenager is not a homogeneous category and how other variables such as class impacted on spatial reach with the more privileged teenage members of the Advisory Group having more inter-community experiences of Belfast based on their peer networks and the networks of their parents. Hence, inter- and intra-generational relationships played out differently for both groups.

Agency also had nuanced effects and resistance took various forms. Children's are holders of knowledge about their social worlds and can appropriate, transform, challenge and resist the various participatory practices that accompanies childhood research. They can go against adult consent for them to participate by resisting the intrusion into their everyday lives through implementing a series of tactics (deCerteau, 1984) such as not filling in questionnaires, obstructing the researcher's implementation of creative methods or by silence although Spyrou 
cautions against viewing silence as non-participation. But my point here is following Gallagher (2009:93) is that "rather than needing to be given "power" by participatory techniques, children may exercise power by resisting, redirecting or subverting those very techniques'. Hence, at multiple points they can negotiate and dilute the underlying power dynamics that often accompanies collaborative research.

There are other examples where resistance was part and parcel of teenagers' everyday lives. The young people from interface communities resisted wider negative portrayals of their communities by demonstrating pride in their area. Reay's (2000:157) research into deprived communities in the UK argues that teenagers often develop strategies and 'tactics for fighting free of negative emplacement'. Young people also resisted discourses passed from parents or reworked these discourses. They questioned parents' accounts of the history of Northern Ireland and relationships between Catholics and Protestants by indicating that they had grown up a different time period and were more forward thinking yet it was clear that segregation and sectarianism continued to impact on the everyday spatial practices of the teenagers from interface areas suggesting messy and contradictory conceptions of ethno-national identity (Leonard, 2017). Their usage of city centre spaces showed resistance in that they created their own urban spaces in ways not envisaged by adults. While, various parts of the city centre reflected spatial generational-segregated spaces, young people reclaimed and occupied these spaces using public spaces as sites for skateboarding or sites where teen sub-cultures could congregate and make their presence felt as legitimate stakeholders of central city spaces. In these ways, they challenged their exclusion from the policy and branding politics of the city which typically excluded their presence in city life and often deemed them as 'out of place' (Sibley, 1995).

In all these ways and in their daily interactions with adults within their families and households, within their community neighbourhood structures, with adults as teachers and youth leaders and with policymakers in their usage of city centre space, these teenagers practiced agency but this agency took place within generational locations. This is not to negate the agency that takes place within peer groups but often these peer groups emanated from their structural positioning as teenagers. For those who resided in segregated interface communities, their economic dependency on adults and the structural framework of Northern Irish society through its residential and educational policies impacted on their autonomy in relation to spatial movements. All these points of resistance demonstrate how power and agency is exercised across and within diverse and ambiguous webs of relationships further demonstrating how 
power and agency are practiced not possessed. While power and agency operate through a multitude of everyday social relationships within and across childhood and adulthood, and while these relationships are unstable, uncertain, fluid and ambivalent producing various albeit often small scale points of resistance and while these sites of practice can of course impact on wider societal structures, the implications for childhood and adulthood is performed and challenged need further exploration. The practice of agency depends on the deployment of available resources. The extent to which children can engage in radical transformation is uncertain and restricted due to the broader set of power relationships within which they everyday lives are located and experienced which at times do little more than support and reproduce the status quo.

\section{Conclusion}

In this article, I have articulated the relevance of the conference theme of precarity, rights and resistance as a triple lens through which to examine and understand children's everyday lives. These three themes provide opportunities for reflection on the complexity and messiness of children's lives in contemporary 'developed' societies. I applied this approach to illuminate the perceptions and experiences of teens growing up in 'post conflict' Belfast. Drawing on the notion of 'social generation' (Wyn and Woodman, 2006) in youth studies and 'generational order' (Qvortrup, 1994) in childhood studies, I introduced the concept of generagency and is associated components of intra and inter-generagency as a useful conceptual tool for exploring the multiple and contradictory landscapes of childhood and adulthood and the generational effects of precarity, rights and resistance. These multi-layered inter-generational relationships are characterised by constantly shifting boundaries played out and negotiated within the multiple spaces in which power, resistance and agency are practiced and achieved.

\section{Footnote:}

The research on teenagers growing up in post-conflict Belfast was supported by an ESRC Grant - Grant Number RES-060-25-0015

\section{References}

Alanen, L. (1994) 'Gender and Generation: Feminism and the "Child Question"', in Qvortrup, J., Bardy, M. Sigritta, G. and Wintersberger, H. (eds) Childhood Matters: Social Theory, Practice and Politics, Aldershot: Avebury. 
Alderson, P. and Goodman, M. (1993) Contradictions within Concepts of Children's Competence, The International Journal of Children's Rights, 1, 303-313. (check ref doesn't seem right)

Archard, D. and Skivenes, M. (2009) Balancing a Child's Best Interests and a Child's Views, The International Journal of Children's Rights, 17, 1-21.

Besson, S. (2005) 'The Principal of Non-Discrimination in the Convention on the Rights of the Child', The International Journal of Children's Rights, 13, 4, 433-61.

Cahill, C. (2009) Doing Research with Young People: Participatory Research and the Rituals of Collective Work, in van Blerk, L. and Kesby, M. (eds.) Doing Children's Geographies. Methodological Issues in Research with Young People, London: Routledge.

Cooke, B. and Kothari, U. (2001) The Case for Participation as Tyranny in Cooke, B. and Kothari, U. (eds) Participation: The New Tyranny, London: Zed Books.

de Certeau, M. (1984) The Practice of Everyday Life, Berkeley, California: University of California Press.

Foucault, M. (1980) in C. Gordon (ed) Power/Knowledge: Selected Interviews and Other Writings, 1972-1977, London: Routledge.

Franks, M. (2011) 'Pockets of Participation: Revisiting Child-Centred Participation Research', Children and Society, 25, 1, 15-25.

Freeman, M. (1996) Children's Rights: A Comparative Perspective, Aldershot: Dartmouth.

Gallacher, L. and Gallagher, M. (2008) 'Methodological Immaturity in Childhood Research? Thinking Through Participatory Methods', Childhood, 15, 4, 499-516.

Gallagher, M (2009) Rethinking Participatory Methods in Children's Geographies, in van Blerk, L. and Kesby, M. (eds.) Doing Children's Geographies. Methodological Issues in Research with Young People, London: Routledge.

Ginwright, S. and James, T. (2002) From Assets to Agents of Change: Social Justice, Organising and Youth Development, New Directions for Youth Development, 96, 27-46.

Gore, J. (1992) What can we do for you! What can we do for you?? Struggling over Empowerment in Critical and Feminist Pedagogy. in Luke, C. and Gore, J. (eds) Feminism and Critical Pedagogy, London: Routledge, pp. 54-73.

Grover, S. (2004) Why Won't They Listen to Us? On Giving Power and Voice to Children Participating in Social Research, Childhood, 11, 1, 81-93.

Hamilton, J., Hasson, U., Bell, J. and Toucas, S. (2008) Segregated Lives: Social Divisions, Sectarianism and Everyday Life in Northern Ireland, Belfast: Institute for Conflict Research.

Kitchen, R. and Hubbard, P. (1999) Research Action and 'Critical' Geographies, Area, 31, $195-$ 98.

Lee, N. (1998) Towards an Immature Sociology, The Sociological Review, 46, 3,458-81. 
Leonard, M. (2017) Teens and Territory in Post-Conflict Belfast: If Walls Could Talk, Manchester, Manchester University Press.

Leonard, M. (2016) The Sociology of Children, Childhood and Generation, London: Sage.

Leonard, M. (2007) With a Capital "G": Gatekeepers and Gatekeeping in Research with Children in Best, A. (ed) Representing Youth: Methodological Issues in Critical Youth Studies, New York: New York University Press.

Lewis, J. (2006) Children, Changing Families and Welfare States, Cheltenham: Edward Elgar. Mayall, B. (2002) Towards a Sociology for Childhood, Buckinghamshire: Open University Press.

Merz, E. (2013) 'The Long Reach of Childhood: Childhood Experiences influence Close Relationships and Loneliness Across Life', Advances in Life Course Research, 18,3, 212-22.

OFMDFM (Office of the First Minister and Deputy First Minister) (2010) Programme for Cohesion, Sharing and Integration: Consultation Document, Belfast: Office of the First Minister and Deputy First Minister.

Pain, R. (2004) Social Geography: Participatory Research, Progress in Human Geography, 28, $5,652-63$.

Prout, A. (2005) The Future of Childhood, London: Routledge/Falmer.

Prout, A. and James, A. (1990) A New Paradigm for the Sociology of Childhood: Province, Promise and Problems in James, A. and Prout, A. (eds.) Constructing and Reconstructing Childhood, Basingstoke: Falmer Press.

Punch, S. (2002) Research with Children: The Same or Different from Research with Adults? Childhood, 9, 3, 321-41.

Qvortrup, J. (1994) 'Childhood Matters: An Introduction' in Qvortrup, J., Bardy, M. Sigritta, G. and Wintersberger, H. (eds) Childhood Matters: Social Theory, Practice and Politics, Aldershot: Avebury.

Reay, D. (2000) Children's Urban Landscapes: Configurations of Class and Place, in Munt, S.R. (ed) Cultural Studies and the Working Class, London: Cassell.

Schafer, N. and Yarwood, R. (2009) Involving Young People as Researchers: Uncovering Multiple Power Relations among Youths, in van Blerk, L. and Kesby, M. (eds.) Doing Children's Geographies. Methodological Issues in Research with Young People, London: Routledge.

Shirlow, P. and Murtagh, B. (2006) Belfast: Segregation, Violence and the City, London: Pluto Press.

Shuttleworth, I. and Lloyd, C. (2008) Mapping Segregation on Belfast NIHE Estates, Belfast: Northern Ireland Housing Executive.

Sibley, D. (1995) Geographies of Exclusion, London: Routledge. 
Wyness, M. (2009) 'Children Representing Children: Participation and the Problem of Diversity in UK Youth Councils', Childhood, 16, 4, 535-52. 